\title{
Peran Sistem Informasi Dalam Meningkatkan Investasi Asing Pada Sektor Properti Di Indonesia Di Era Pasar Bebas
}

\author{
Yosi Agustiawan \\ Sistem Informasi, Fakultas Teknik, Universitas Pesantren Tinggi Darul ‘Ulum (Unipdu), Jombang \\ E-mail: yosiagustiawan@ft.unipdu.ac.id
}

\begin{abstract}
Abstrak
Pasar bebas adalah hasil dari proses globalisasi yang telah menciptakan integrasi ekonomi antar negara. Artikel ini mengkaji dampak globalisasi di pasar properti global dan peran sistem informasi untuk meningkatkan investasi asing di Indonesia. Meningkatnya investasi asing langsung (Foreign Direct Investmen/FDI) yang mengalir ke negara berkembang termasuk Indonesia di berbagai sektor termasuk properti telah memberikan banyak manfaat untuk meningkatkan ekonomi. Buruknya peraturan kepemilikan tanah dan infrastruktur adalah masalah utama yang harus diatasi untuk menjaga agar investor asing masih berniat untuk menanamkan modalnya dalam pasar properti global. Sistem informasi dapat digunakan sebagai alat yang efektif untuk mengatasi masalah-masalah tersebut melalui penggunaan e-government dan perencanaan strategis implementasi sistem informasi dalam proyek infrastruktur.
\end{abstract}

Kata kunci: globalisasi, investasi asing, pasar properti global, e-government, sistem informasi.

\begin{abstract}
Cross-border relationships do not only affect many aspects but it also creates economic integration among countries. This essay examines the impact of globalization on the property market and the role of information system to promote foreign direct investment (FDI) in Indonesia. Allowing foreign direct investment (FDI) flows to those developing in various industries including property has clearly provided positive opportunities to improve their economic. Poor land regulations and infrastructure are the main issues that must be overcome to maintain foreign investor still intend to capitalize on the global property market. Information system can be used as effective tool to resolve those issues through e-government and strategic implementation in projects infrastructure.
\end{abstract}

Key word: globalization, foreign direct investment, global property market, e-government, system information.

\section{Pendahuluan}

Globalisasi adalah proses yang tak terelakkan, yang mempengaruhi perubahan dalam aspek politik, ekonomi, sosial, dan teknologi. Interaksi manusia di seluruh dunia dalam bidang ini sangat intensif dan tanpa batas. Proses ini menciptakan banyak peluang, yang merupakan faktor penentu bagi banyak negara terutama dalam mengembangkan dan meningkatkan ekonomi mereka. Mengijinkan sumber dari negara lain termasuk manusia, investasi, barang, dan jasa mengalir ke negara-negara berkembang dapat meningkatkan pertumbuhan ekonomi. Negara-negara berkembang seperti Indonesia akan memperoleh banyak manfaat ekonomi ketika mereka membuka pasarnya termasuk pasar properti meskipun terdapat beberapa kendala. Beberapa kendala tersebut dapat diselsaikan melalui penerapan sistem informasi yang tepat.

Banyak investor asing masih melihat pasar properti global di negara-negara berkembang memiliki potensi tingkat pengembalian yang lebih tinggi atas investasi dan saat ini terus berkembang pesat. Menurut data dari Prudential Real Estate Investor (2012), selama periode 10 tahun antara 2001 sampai dengan 2011, negara-negara berkembang seperti China, India, Brazil dan Indonesia secara dominan memberikan kontribusi terhadap pertumbuhan pasar properti global. Mereka juga memprediksi bahwa pada tahun 2021, kontribusi pertumbuhan pasar properti global China akan meningkat tajam hingga mencapai 35\%, sementara itu kontribusi India dan Indonesia akan mencapai lebih dari dua kali lipat dari sebelumnya pada periode tahun 2011 sampai dengan 2021, masing-masing dari 1,2\% menjadi 2,5\% dan 2,1\% menjadi 5,8\%. Selanjutnya, Choy dkk (2011) juga menyatakan bahwa dengan adanya kenaikan PDB (Produk Domestik Bruto) di negara-negara berkembang seperti Malaysia, transaksi perdaganan properti juga meningkat secara signifikan. 
Meskipun banyak manfaat ekonomi yang didapat dengan membuka pasar properti di Indonesia bagi investor asing, namun beberapa kendala yang ada perlu di kurangi melalui peran sistem informasi dalam upaya meningkatkan investasi asing pada sektor properti di indonesia di era pasar bebas. Untuk itu perlu dicari alternatif solusi untuk mengurangi faktor utama yang manjadi penghambat investor asing menanamkan modalnya di pasar properti sesuai dengan fungsi sistem informasi.

\section{Permasalahan}

\subsection{Manfaat Investasi Asing}

Banyak negara berkembang di era global sangat bergantung pada penanaman modal asing (Foreign Direct Investment, FDI) atau investasi lintas negara. FDI dapat memberikan modal dalam jumlah besar yang sangat diperlukan untuk mengerakan perekonomian negara berkembang. Negaranegara tersebut memerlukan barang atau jasa serta tenaga kerja dan sumber daya lainnya untuk menggerakan ekonominya tetapi mereka tidak memiliki dukungan finansial yang cukup untuk memulai produksi. Menurut data dari United Nations Conference on Trade and Development/ UNCTAD (2015) selama 20 tahun antara 1995 sampai dengan 2014, telah terjadi peningkatan tajam dalam jumlah FDI di negara berkembang dari sekitar \$ 117 miliar menjadi sekitar \$ 681 miliar. Selain itu, PBB juga melaporkan bahwa arus masuk FDI di wilayah ini mencapai lebih dari 50 persen dari total investasi asing dunia. China, Brazil dan India berada pada sepuluh besar penerima FDI pada tahun 2015.

\subsection{Peluang Pasar Properti Di Negara Berkembang}

Investor asing biasanya menanamkan modalnya di berbagai industri seperti perbankan, teknologi, manufaktur, pertambangan, dan pertanian. Umumnya, investasi asing di industri properti jauh lebih kecil daripada di sektor lain. Data dari Organisasi Kerjasama Ekonomi dan Pembangunan (Organisation for Economic Co-operation and Development, OECD) (2015), misalnya, mengungkapkan bahwa pada tahun 2007, total investasi Amerika Serikat (USA) di luar negaranya pada sektor manufaktur adalah \$ 71.977.000. Angka ini secara signifikan lebih tinggi daripada di properti termasuk konstruksi, yang secara keseluruhan menyumbang hanya \$3.788.000. Namun demikian, kegiatan perusahaan multinasional USA berkaitan dengan investasi di negara-negara tertentu membuka peluang berharga bagi para investor baik individu maupun perusahaan untuk memanfaatkan pasar properti di mana industri AS beroperasi (Moshirian dan Pham, 2000).

Sementara itu perbedaan antara FDI di bidang manufaktur dan properti di negara-negara berkembang tidak benar-benar signifikan. Rao dan Dhar (2011) melaporkan bahwa, pada tahun 2007, India menyerap FDI sebesar \$ 18.670 .000 di bidang manufaktur, jumlah ini hanya sedikit berbeda dari yang diinvestasikan dalam sektor properti dan konstruksi sebesar \$17.410.000. Moshirian dan Pham (2000) juga menemukan bahwa ekspansi perusahaan multinasional perusahaan-perusahaan AS di bidang manufaktur umumnya akan disertai dengan investasi di bidang properti. Hal ini disebabkan karena perusahaan multinasional AS ingin memberikan pelayanan langsung kepada pelanggan mereka di luar negeri. Fereidouni dan Masron (2013) juga menyatakan bahwa di negara-negara berkembang, FDI di sektor lain memberikan kontribusi yang sangat berarti untuk meningkatkan FDI di sektor properti.

Newell dan Worzala (1995) berpendapat bahwa faktor utama yang mendorong minat investor asing untuk berinvestasi di pasar properti global adalah; likuiditas yang lebih baik dari pasar properti asing, deregulasi kepemilikan, perubahan kebijakan investasi asing, pertumbuhan ekonomi yang tinggi, meningkatkan interaksi global, dan berkembangnya informasi. Meskipun demikan beberapa masalah timbul ketika investor asing berniat untuk membeli properti di negara berkembang. Akibatnya, pasar properti global bervariasi dalam ukuran di berbagai negara. Pada tahun 2012 data dari Prudential Real Estate Investor mengungkapkan bahwa, meskipun PDB Thailand lebih tinggi dibandingkan Malaysia (\$ 344.000.000.000 dibandingkan dengan \$265.000.000.000), proporsi pasar properti global terhadap PDB di Malaysia lebih kecil dibandingkan dengan di Thailand (25,9\% dibandingkan dengan 31,6\%).

\subsection{Permasalahan Umum Pasar Properti Global Di Negara Berkembang}

Negara-negara berkembang mengadopsi globalisasi di pasar properti mereka dengan berbagai cara tergantung pada faktor sosial-ekonomi seperti: pendidikan, tradisi, politik, ekonomi dan teknologi. Akinbogun dkk (2014) menjelaskan, "Kendala pasar properti bervariasi di negara-negara berkembang

2| Register: Jurnal Ilmiah Teknologi Sistem Informasi, Januari 2016, Volume 2, Nomor 1 
dengan berbagai perbedaan aturan, misalnya, dalam hukum sewa, perencanaan, dan prosedur pendaftaran tanah".

Masalah lain adalah tidak efektifnya perencanaan wilayah dan kota besar yang sering tidak dapat mengantisipasi pertumbuhan penduduk perkotaan yang pesat. Hal ini menurut Akinbogun dkk (2014) disebabkan oleh kurangnya sumber daya yang mampu merancang secara menyeluruh berbagai komponen rencana induk termasuk pengendalian banjir, penggunaan lahan, dan infrastruktur. Alasan lain adalah berlapis-lapisnya urusan administrasi birokrasi yang mampu melemahkan proses pengambilan keputusan. Para politisi sering mengambil keuntungan dari situasi ini untuk kepentingan mereka. Kombinasi perencanaan yang buruk dan keengganan para pembuat kebijakan untuk secara konsisten memenuhi rencana induk (master plan) menyebabkan banyaknya perubahan dalan rencana induk tata kota. Hasil ini terjadi terus-menerus sehingga di daerah perkotaan banyak proyek properti yang dibangun tanpa perencanaan yang disetujui pihak berwenang. Masalah-masalah ini dapat menghambat keinginan investor asing untuk berinvestai seperti yang dikemukakan oleh Newell dan Worzala (1995). Para investors asing khawatir tentang kondisi politik yang sangat mempengaruhi kepastian iklim berusaha.

\subsection{Permasalahan Pasar Properti Global Di Indonesia}

Tidak berbeda dengan negara berkembang lain hambatan utama yang dialami oleh investor asing dalam berinvestasi pada sektor properti di Indonesia adalah peraturan perundangan yang kurang menarik bagi para investor untuk memiliki properti di Indonesia. Peraturan kepemilikan properti misalnya masih menggunakan peraturan yang sudah berusia lebih dari 50 tahun yaitu Undang-Undang Pokok Agraria (UUPA) tahun 1960. Dalam peraturan ini diatur penguasaan properti oleh asing dan Badan Hukum Asing yang mempunyai perwakilan di Indonesia hanya berhak memiliki hak guna dan ha sewa. Jangka waktu penggunaan hak atas properti yang pendek juga mengurangi daya saing pasar properti Indonesia dangan negara lain. Peraturan Pemerintah (PP) No 40/1996 mengatur investor asing hanya dapat menggunakan hak atas propertinya selama 25 tahun yang tidak dapat diperpajang namun dapat diperbaharui selama 20 tahun. Sementara di Malaysia investor asing dapat menggunakan haknya selama 90 tahun (Hadisusilo, 2009).

Dalam hal kondisi infrastruktur utama seperti jalan, listrik dan telekomunikasi dan fasilitas pendukung dasar seperti kebersihan, pendidikan dan kesehatan di kota-kota besar seperti Jakarta, Surabaya dan Medan yang menjadi sasaran investor asing untuk membeli properti kurang kondusif dibanding negara lain. Hal ini dapat dilihat dari data dari (UN-Habitat, 2002) yang melakukan penilaian kota-kota di dunia menghasilkan indeks pembangunan kota (City Development Index, CDI) tiga kota besar di Indonesia lebih kecil dari negara tetangga, di mana CDI dari Jakarta, Surabaya dan Medan adalah 69.2, 58 dan 62,2, sementara CDI Bangkok dan Hanoi masing-masing 82,6 dan 74,2.

\subsection{Sistem Informasi Sebagai Alat Solusi}

Sistem informasi sudah terbukti mampu mempermudah aktivitas manusia sehari-hari di berbagai aspek baik di bidang pendidikan, pemerintahan dan bisnis. Hal ini menurut O'Brien dan Marakas (2010) dikarenakan peran sistem informasi mampu mendukung fungsi dari area bisnis untuk mencapai tujuan, meningkatkan efisiensi kerja, efektif sebagai sumber utama informasi dalam mendukung pengambilan keputusan, dan mampu digunakan untuk mengembangkan produk dan jasa yang kompetitif.

Peran sistem informasi dalam meningkatkan efisiensi kerja dan efektifitas sumber informasi yang diterapkan pada pemerintahan berupa electronic government (e-government), misalnya bermanfaat menyederhanakan birokrasi sehingga mampu memperlancar berbagai macam proses administrasi yang pada gilirannya mampu meningkatakan kinerja pemerintahan. Menurut (Hasibuan, 2007) e-government adalah bentuk layanan informasi antar lembaga pemerintah (Government to Government-G2G), lembaga pemerintahah kepada dunia usaha (Government to Business-G2B) dan lembaga pemerintah kepada masyarakat (Government to Citizen-G2C). Lebih lanjut ia menyatakan bahwa e-government yang sistematis dapat memberikan manfaat untuk menurunkan biaya administrasi, meningkatkan pelayanan kepada publik secara cepat dan akurat, dan mempermudah koordinasi antar lembaga pemerintahan baik di pusat maupun di daerah.

Manfaat lain dari penggunaan sistem informasi dalam mengembangkan produk dan jasa dapat terlihat dari digunakanya pada perencanaan dan pelaksanaan proyek-proyek infrastruktur. Hasil penelitian dari Sandhyavitri dkk (2013) mengungkapkan bahwa teknologi informasi adalah faktor yang

Register: Jurnal Ilmiah Teknologi Sistem Informasi, Januari 2016, Volume 2, Nomor 1 | 3 
signifikan bagi perusahaan-perusahaan jasa konstruksi untuk meningkatkan produktivitasnya dan kinerjanya sehingga mampu berkompetensi di era global.

\section{Pembahasan}

Untuk meningkatkan keinginan investor asing untuk memiliki properti di Indonesia maka faktor penghambat berupa peraturan perundangan perlu dikurangi. Mengingat perundang-undangan memerlukan proses politik yang panjang untuk mengubahnya, maka diperlukan alternatif lain untuk mengurangi hambatan tersebut. Kemudahan memperolah informasi dan proses administrasi melalui layanan e-government adalah salah satu alternatif. Center for Democracy and Technology dan InfoDev menyatakan dalam (Hasibuan, 2007) bahwa ada 3 (tiga) tahapan implementasi sistem informasi yang tidak tergantung antara yang satu dengan yang lainnya yang mampu menjadi solusi tersebut, adapun tahapan itu adalah:

a. Publish, yaitu tahapan penggunaan sistem informasi untuk memudahkan akses informasi misalnya melalui pembuatan situs.

b. Interact, yaitu tahapan meningkatkan interaksi masyarakat dalam pemerintahan, dan antar lembaga pemerintah misalnya melalui media sosial dan surat elektronik.

c. Transact, yaitu tahapan melakukan layanan pemerintah secara daring (online), misalnya dengan cara pembuatan aplikasi prosedur perijinan.

Sistem informasi yang menyeluruh, mudah di akses dan selalu diperbaharui (update) seperti pada tahap publish dan interact sangat membantu para investor dalam mencari informasi mengenai harga, lokasi dan ketentuan kepemilikan. Sementara tahapan transact selain memudahkan proses administrasi juga mengurangi birokrasi.

Kerumitan dan kompleksitas proyek-proyek infrastruktur juga perlu diurai melalui penggunaan sistem informasi yang tepat sesuai dengan kondisi dan budaya kerja di Indonesia. Hal ini merlukan perencanan strategis yang matang dalam mengimplementasikan sistem informasi dalam proyek infrastruktur sehingga ketersediaan infrastruktur di Indonesia dapat sesuai dengan keinginan investor. Suatu studi yang dilakukan pada perusahan di Australia oleh (Stewart dkk, 2002) mengungkapkan bahwa rencana strategis implementasi sistem informasi pada proyek skala besar yang baik mampu memberikan keuntungan bagi pekerjaan konstruksi. Keuntungan tersebut berupa:

a. Terbukanya kesempatan untuk melakukan kerja-sama strategis dengan dunia internasional.

b. Memfasilitasi kerja-sama strategis internasional tersebut.

c. Akses informasi proyek internasional terbuka luas.

d. Koordinasi dan komunikasi antar pelaku proyek dapat meningkat

e. Mampu menarik lebih banyak banyak proyek-proyek lokal maupun internasional.

f. Dapat menyimpan data elektronik proyek dari konseps sampai selesainya prosek.

g. Dapat meningkatkan pengendalian dokumen yang dapat mengurangi biaya administrasi

h. Implementasi Sistem Informasi (SI) mampu mobilisasi dengan cepat tenaga kerja pada $b$ berbagai proyek

i. Mengurangi penggunaan kertas sehingg mengurangi biaya administrasi.

\section{Kesimpulan}

Negara-negara berkembang, khususnya yang secara efektif mengambil manjadi bagian dalam ekonomi global, mendapat keuntungan ekonomi yang sangat besar. Banyak penelitian menunjukkan bahwa arus masuk investasi asing di berbagai sektor termasuk properti mendorong pertumbuhan ekonomi. Industri properti telah terbukti sebagai peran penting dalam perekonomian seperti yang telah sangat berkontribusi terhadap PDB dari bangsa-bangsa. Indonesia sebagai salah satu negera berkembang harus mengambil langkah-langkah untuk menarik banyak investasi asing dengan jalan mempermudah investasi asing di sektor properti melalui perbaikan peraturan dan mengembangkan fasilitas dan infrastrukturnya.

Hasil sebuah survei yang mengungkapkan bahwa banyak investor masih berniat untuk berinvestasi di pasar properti global sepanjang adanya peningkatan dalam deregulasi kepemilikan, perubahan kebijakan investasi asing, pertumbuhan ekonomi yang tinggi, peningkatkan interaksi global, dan berkembangnya serta terbukanya informasi harus dimanfaatkan oleh Indonesia. Untuk itu pemanfaatan sistem informasi di pemerintahan berupa $e$-government perlu dikembangkan. Perancanaan

4 | Register: Jurnal Ilmiah Teknologi Sistem Informasi, Januari 2016, Volume 2, Nomor 1 
strategis implementasi sistem informasi dalam proyek-proyek infrastruktur juga perlu mendapat perhatian agar penggunaannya sesuai dengan budaya kerja bangsa Indonesia. Kedua hal tersebut jika dilakukan dengan sungguh-sungguh dan terencana dengan baik diharapkan dapat meningkatkan arus investasi asing terutama di sektor properti.

\section{Referensi}

Akinbogun, S., Jones, C., \& Dunse, N. (2014). The Property Market Maturity Framework and its Application to a Developing Country: The Case of Nigeria. Journal of Real Estate Literature, 22(2), 217-232.

Choy, C. F., Skitmore, M., Runeson, G., \& Bridge, A. (2011). Property Investment, Construction and Economic Growth: The Case of Malaysia. In The Asian Conference on Real Estate (ACRE 2011) : Sustainable Growth, Management Challenges. Thistle Johor Bahru, Malaysia: QUT ePrints.

Fereidouni, H. G., \& Masron, T. A. (2013). Real Estate Market Factors and Foreign Real Estate Investment. Journal of Economic Studies, 40(4), 448 - 468.

Hadisusilo, A. S. (2009). Perbandingan Hukum Perolehan Hak Atas Tanah Untuk Orang Asing Di Indonesia Khususnya Di Pulau Batam Dengan Orang Asing Di Negara Malaysia (Doctoral dissertation, program Pasca Sarjana Universitas Diponegoro).

Hasibuan, Z. A. (2007). Langkah-Langkah Strategis dan Taktis Pengembangan E-Government untuk Pemda. Jurnal Sistem Informasi MTI UI, 3(1), 6-70.

Moshirian, F., \& Pham, T. (2000). Determinants of US Investment in Real Estate Abroad. Journal of Multinational Financial Management, 10(1), 63-72.

Newell, G., \& Worzala, E. (1995). The Role of International Property in Investment Portfolios. Journal of Property Finance, 6(1), 55 - 63.

O’Brien, J. A. \& Marakas, G.M. (2010). Management Information Systems. Eight Edition. New York : McGraw-Hill/Irwin.

OECD. (2015). FDI flows by industry. Retrived November 9, 2015, from http://stats.oecd.org/index. aspx ?DatasetCode=FDI_FLOW_INDUSTRY.

Prudential Real Estate Investor. (2012). A bird's eye view of global real estate Market: 2012 Update.

Rao, K.S.C., \& Dhar, B. (2011). India's FDI inflows trends and concepts.

Stewart, R. A., Mohamed, S., \& R. D. (2002). Strategic Implementation of IT/IS Projects in Construction:. Automation in Construction, 11(2002), 681 - 694.

Sandhyavitri, A., Rahayu,D., \& Venesha, T. (2013). Significant Factors Affecting Contraktor And Consultant Companies' Competitiveness Facing The Global Market Based On The Analytical Hierarchy Process (AHP). Eco Rekayasa vol 9, No.2, 2013.

UNCTAD, U. N. (2015). Foreign Direct Investment: Inward and Outward Flows and Stock, Annual, 1980-2014. Geneva, Switzerland : UNCTAD.

UN-Habitat. (2002). Global Urban Indicators Database Version 2. UN-Habitat. 